\title{
METABOLISMO DO ÁCIDO FÓLICO NA MALÁRIA
}

\author{
Aymoré Vaz Pinto, Mércia Cardoso Paiva, \\ Marina Dantas Alencar Milfont, Lucia Chiarini, Cristina Maria \\ de Lemos Ferreira, Aluizio Prata, João Barberino Santos e \\ Fernando Alexandrino Alves dos Santos
}

\begin{abstract}
$O$ estudo de 27 pacientes infectados pelo Plasmodium falciparum comparado com pessoas aparentemente sadias mostra: a) diminuição do folato no soro dos pacientes infectados; b) diminuição do folato sérico nos primeiros 8 dias que seguiram ao tratamento, interpretados como sendo devido à mobilização pela eritropoiese compensadora; c) folato eritrocítico normal.
\end{abstract}

Palavras chaves: Folato sérico. Folato eritrocítico. Malária.

Vários autores têm estudado o metabolismo do ácido fólico na malária na tentativa de explicar porque drogas antifólicas são úteis no tratamento desta infecção ${ }^{1459}$ ou quais cofatores enzimáticos do ciclo do ácido fólico utilizados no processo da síntese do ADN pelo plasmódio ${ }^{3}$.

Tong e cols. ${ }^{6}$, em 1970, num estudo realizado em 75 casos de malária no Vietnam observaram que o ácido fólico e folínico evitam a megaloblastose mas não impedem o efeito antimalárico, sugerindo que os cofatores enzimáticos humanos não seriam utilizados pelo parasito.

Nosso trabalho que objetiva conhecer o comportamento do ácido fólico na malária, consistiu em: a) conhecer os níveis de ácido fólico sérico e eritrocítico do indivíduo parasitado, antes e após o tratamento, comparando-os com normais; b) explorar a possibilidade de constatar a existência de correlação entre as variáveis ácido fólico sêrico, ácido fólico eritrocítico e hematócrito.

\section{MATERIAL E METODOS}

O material biológico foi colhido na região de Porto Velho, zona endêmica de malária, de 27 pes-

Trabalho realizado na Universidade de Brasília, com ajuda financeira do CNPq.

Recebido para publicação em 30-3-83. soas clinicamente sadias e de 27 pacientes com infecção hemosporídica pelo Plasmodium falciparum, diagnosticada pelo método da gota espessa.

Os grupos de controle e de pacientes pertenciam ao mesmo extrato social e faixa etária. $O$ grupo de controle estava constituído por 22 indivíduos do sexo masculino e 5 do sexo feminino.

O tratamento da infecção foi feito com Mefloquina: WR (142-490, A 4 quinolinemethanol) na dose média de $1000 \mathrm{mg}$, administrada em duas parcelas iguais no primeiro e segundo dias pela manhã. Cinco indivíduos clinicamente normais, funcionários da Universidade de Brasília, também se submeteram ao medicamento, na mesma dose e condições dos pacientes, para verificação do efeito da droga sobre os parâmetros estudados.

As amostras sanguíneas foram colhidas com o paciente em estado de jejum, antes do tratamento. Uma segunda e terceira amostras foram também obtidas no quarto e oitavo dias após a medicação anti-malárica, para a realização dos seguintes exames: hematócrito (micro); ácido fólico sérico ${ }^{8}$; ácido fólico eritrocítico ${ }^{3}$; e índice de parasitemia.

\section{RESULTADOS}

A caracterização do grupo de controle quanto aos valores de hematócrito, ácido fólico sêrico e ácido fólico eritrocítico, se encontra na Tabela 1. 
Tabela 1 - Média, desvio e amplitude dos valores de hematócrito (HTO), ácido fólico sérico (AF-S) e ácido fólico eritrocítico (AF-E) do grupo de controle (27 casos)

\begin{tabular}{lcccc}
\hline & X & DP & A \\
HTO & 39,6 & 3,8 & 32 & -45 \\
AF-S $(\mathrm{ng} / \mathrm{ml})$ & 8,5 & 5,3 & 4,4 & - \\
AF-E $(\mathrm{ng} / \mathrm{ml})$ & 352 & 132 & 133 & -627 \\
\hline
\end{tabular}

O efeito da medicação sobre os niveis de hematócrito, ácido fólico sérico e ácido fólico eritrocítrico, nos 5 indivíduos controles, não foi impor- tante. Os resultados obtidos antes da medicação e quatro dias após, se observam na Tabela 2.

Tabela 2 - Resultados de hematócrito (HTO), acido fólico sérico $(A F-S)$ e ácido fólico eritrocítico $(A F-E)$, dos 5 indivíduos controles antes (A1) e 4 dias após (A2) a administração da mefloquina.

\begin{tabular}{|c|c|c|c|}
\hline & HTO & $A F-S$ & $A F-E$ \\
\hline & $\mathbf{A}_{1} \quad \mathbf{A}_{2}$ & $\mathbf{A}_{1} \quad \mathbf{A}_{2}$ & $\mathbf{A}_{1} \quad \mathbf{A}_{2}$ \\
\hline OFC & $\begin{array}{ll}48 & 48\end{array}$ & $8,6 \quad 6,2$ & 515485 \\
\hline JLC & $44 \quad 45$ & $9,3 \quad 8,1$ & $488 \quad 470$ \\
\hline DFS & $46 \quad 47$ & $14,0-$ & $696-$ \\
\hline HS & $43 \quad 44$ & $9,7 \quad 8,7$ & $345 \quad 352$ \\
\hline JVP & $49 \quad 49$ & $3,5 \quad 6,6$ & $388 \quad 380$ \\
\hline
\end{tabular}

$O$ indice de parasitemia calculado em relação aos leucócitos e expressado em parasitos por $\mathrm{mm}^{3}$ de sangue, nos 25 casos em que foi determinado, apresentou uma média de $12.636 / \mathrm{mm}^{3}$, variando de 400 a $80.000 / \mathrm{mm}^{3}$

A parasitemia desapareceu nos primeiros dias após o tratamento, chegando ao quarto dia com ausência de parasitos no sangue, exceção feita a um paciente o qual, no quarto dia, apresentava 15 parasitos por $\mathrm{mm}^{3}$.

A média, o desvio padrão e a amplitude dos valores do hematócrito, antes e depois do tratamento, encontram-se na Tabela 3. 
Pinto AV, Paiva MC, Milfont MDA, Chiamini Z, Ferreira CML, Prata A, Santos JB, Santos FAA. Metabolismo do ácido fólico na malária. Revista da Sociedade Brasileira de Medicina Tropical 16:107-111, Abr-Jun, 1983

Tabela 3 - Média desvio padrão e amplitude dos valores de hematócrito nas amostras seriadas dos pacientes, antes (A1) do tratamento e 4 (A2) e 8 (A3) dias após.

\begin{tabular}{llll}
\hline & $\bar{X}$ & DP & A \\
$\mathrm{A}_{1}$ & 41 & 7 & $30-50$ \\
$\mathrm{~A}_{2}$ & 39 & 6 & $28-49$ \\
$\mathrm{~A}_{3}$ & 39 & 4,7 & $31-49$ \\
\hline & $\mathrm{t}=2.43$ & $\mathrm{P}<0.05$ & $\left(\mathrm{~A}_{1} \neq \mathrm{A}_{2}\right)$
\end{tabular}

As variáveis hematócrito, ácido fólico sérico e ácido fólico eritrocítico, apresentaram distribuição normal nas contagens realizadas antes do tratamento, 4 dias após e 8 dias após. $\mathrm{Na}$ apreciação das diferenças entre as amostras, aplicou-se o teste de " $\mathrm{t}$ - pareado", já que as três amostras para cada variável foram obtidas a partir dos mesmos pacientes.

A diminuição do hematócrito nos primeiros 4 dias, com relação aos valores iniciais, é estatisticamente significativa, como demonstrado pelo teste " $t$ " de amostras correlacionadas $(t=2.43)$, $P<0.05$.
Se considerarmos $36 \%$ o mínimo de normalidade para o hematócrito, vamos constatar que a anemia estava presente em $26 \%$ dos pacientes ( 7 casos) antes do tratamento, em $33 \%$ dos pacientes no quarto dia após o tratamento ( 9 casos) e em $22 \%$ dos pacientes no oitavo dia após a medicação (6 casos). No grupo controle apenas 3 indivíduos apresentavam hematócrito abaixo de $36 \%$.

Com relação ao ácido fólico sérico, $21 \%$ dos pacientes apresentavam valores menores que 3,5 $\mathrm{ng} / \mathrm{ml}$ de soro. No grupo controle os valores desta vitamina foram mais elevados. Estes dados indicam que o indivíduo parasitado com $P$. falciparum apresenta uma diminuição dos folatos no soro. (Tabela 4).

Tabela 4 - Incidência de cifras subnormais de ácido fólico nos pacientes e no grupo de controle.

\begin{tabular}{lcc} 
& $<3,5 \mathrm{ng} / \mathrm{ml}$ & $<5.0 \mathrm{ng} / \mathrm{ml}$ \\
& $\%$ & $\%$ \\
Pacientes (24 casos) & 21 & 42 \\
Controle (27 casos) & 0 & 11 \\
\hline
\end{tabular}


Pinto AV, Paiva MC, Milfont MDB, Chiarini L, Ferreira CML, Prata A, Santos JB, Santos FAA. Metabolismo do ácido fólico na malária. Revista da Sociedade Brasileira de Medicina Tropical 16:107-111, Abr-Jun, 1983

Na tabela 5 se observa a média, o desvio padrão fólico nas 3 amostras de soro dos pacientes.

e a amplitude dos resultados da dosagem do ácido

Tabela 5 - Média, desvio padrão e amplitude do ácido fólico sérico nas amostras seriadas de 24 pacientes, antes (A1) e 4 dias (A2) e 8 dias (A3) após a administração da mefloquímica.

$\begin{array}{llll} & \bar{X} & \text { DP } & \text { A } \\ \mathrm{A}_{1} & 6 & 3,7 & 2,4-15,8 \\ \mathrm{~A}_{2} & 4 & 1,9 & 1,9-9,2 \\ \mathrm{~A}_{3} & 3,2 & 0,8 & 2,1-5,0\end{array}$

Dos 24 casos em que determinamos o ácido fólico intra-eritrocítico, este se apresentou subnormal em apenas 2 casos, ou seja, a primeira amostra de um paciente com $128 \mathrm{ng} / \mathrm{ml} \mathrm{de} \mathrm{G.V.} \mathrm{e} \mathrm{a} \mathrm{segunda} \mathrm{e}$ terceira amostras de outro paciente com valores de 147 e $140 \mathrm{ng} / \mathrm{ml}$ de G.V., respectivamente. Os va- lores considerados normais estão compreendidos entre 180 e $600 \mathrm{ng} / \mathrm{ml}$.

A média, o desvio padrão e a amplitude dos valores de ácido fólico eritrocíticos estão na Tabela 6.

Tabela 6 - Média, desvio padrão e amplitude dos valores de ácido fólico eritrocitico $(\mathrm{ng} / \mathrm{ml})$ antes $(\mathrm{Al})$ e 4 dias (A2) e 8 dias (A3) após a administração da mefloquina.

\begin{tabular}{lrrrrr}
\hline & X & DP & & A & \\
A 1 (24 casos) & 362 & 113 & 221 & - & 595 \\
A 2 (14 casos) & 356 & 129 & 147 & - & 705 \\
A 3 (14 casos) & 402 & 214 & 140 & - & 1.000 \\
\hline
\end{tabular}

O teste de correlação linear, aplicado entre as variáveis ácido fólico soro, ácido fólico eritrocítico e hematócrito apresentou os índices de correlação especificados na Tabela 7.

Tabela 7 - Indices de correlação entre variáveis: $\dot{a}$ cido fólico sérico ( $A F-S) x$ ácido fólico eritrocítico $(A F-E) x$ hematócrito HTO.

AF-S HTO

$\begin{array}{lll}\text { AF-S } & 1,00 & 0,08 \\ \text { AF-E } & 0,36 & 0,37\end{array}$

$O$ índice de correlação do ácido fólico do soro $\mathrm{x}$ ácido fólico eritrocítico, ainda que baixo $(r=$ 0.366 ), mostrou ser significativamente diferente $d \epsilon$ "zero", com um valor $\mathrm{t}=1.845$ e $\mathrm{p}<0.05$, para 22 graus de liberdade.

$O$ índice de correlação do ácido fólico eritrocítico $x$ hematócrito, ainda que baixo $(r=-0.379)$, mostrou ser significativamente diferente de "zero", com um valor $\mathrm{t}=1,926$ e $\mathrm{p}<0.05$, para 22 graus de liberdade. Como esta correlação é inversa, se aceitarmos a hipótese de " $r$ " ser diferente de "zero", este dado sugere que a anemia no indivíduo parasitado não está relacionada com deficiência de ácido fólico intra-eritorcítico ou consumo aumentado de ácido fólico do eritrócito pelo parasito. 


\section{DISCUSSĀO}

A diminuição do hematócrito nos primeiros quatro dias após o início do tratamento da malária reflete um estado de hemólise próprio da doença, uma vez que até o terceiro dia ainda eram detectados parasitos no sangue.

Os pacientes afetados de malária pelo Plasmodium falciparum apresentaram valores de ácido fólico sérico com níveis subnormais em uma alta percentagem de casos (42\%). Mas estes valores podem não significar um estado de deficiência no metabólito, pois encontramos ácido fólico eritrocítico dentro dos limites normais ${ }^{2}$. Tal diminuição poderia antes significar uma mobilização do ácido fólico sérico pela eritropoiese de compensação ${ }^{7}$, já que ele não se altera significativamente pelos níveis de Mefloquina no soro.

Sabendo-se que os glóbulos vermelhos constituem o tecido mais rico em folatos no organismo ${ }^{2}$ e que o plasmódio parasita principalmente esta célula, questionamos se o parasito não seria um consumidor de folatos do glóbulo vermelho. Tong" observou que a associação de ácido fólico a drogas antimaláricas pode evitar o desenvolvimento da megaloblastose nas células do hospedeiro. Isto, no entanto, não impede o efeito antiparasitário. Assim, ele sugere que os cofatores enzimáti$\cos$ humanos não sejam utilizados pelo parasito. Os nossos resultados parecem apoiar esta assertiva, pois encontramos valores de ácido fólico intraeritrocítico normais nos indivíduos parasitados antes e após o tratamento. No entanto, o número de glóbulos vermelhos parasitados por $\mathrm{mm}^{3}$ é muito pequeno em relação ao número de glóbulos vermelhos totais contidos em um milimetro cúbico de sangue $\left(12.636 / 4.320 .000 / \mathrm{mm}^{3} \mathrm{em}\right.$ nosso estudo). Tal fato não nos permite afastar a possibilidade de o parasito interferir somente com o ácido fólico eritrocítico do glóbulo parasitado e esta interferência ser diluída e, portanto, mascarada pela grande quantidade de glóbulos vermelhos não parasitados.

\section{SUMMARY}

The study of 27 patients with malaria caused by Plasmodium falciparum compared with normal controls, showed: a) lower serum folate levels in the group of patients; $b$ ) a drop in the serum folate levels during the first eight days of treatment, interpreted as due to the folate mobilisation by the increment of erythropoiesis; c) normal erythrocyte folate levels.

Key words: Serum folate. Erythrocyte folate. Malaria.

\section{REFERENCIAS BIBLIOGRĀFICAS}

1. Ferone, R. Folate metabolism in malaria. Bulletin of World Health Organization 55: 291-298, 1977.

2. Hoffbrand AV, Beverly FA; Newcombe B, Mollin DL. Method of assay of red cell folate activity and the value of the assay as a test for folate deficiency. Journal of Clinical Pathology 19: 17-28, 1966.

3. Platzer EG. Metabolism of tetrahidrofolate in Plasmodium lophurae and duckling erythrocyte. Transaction of the New York Academy of Sciences, series II, 34: 200-207, 1972.

4. Peters $\mathbf{W}$. Chemotherapy and drug resistence in malaria. London Academic Press. 1970.

5. Thompson PE, Webel LM. Antimalarial agents. Chemotherapy and Pharmacology. New York Academic Press, 1972.

6. Tong MJ, Strickland T, Votteri BA, Gunning JJ. Supplemental folates in the therapy of Plasmodium falciparum malaria. Journal of American Medical Association, 214: 2330-2333, 1970.

7. Vaz Pinto A, Torras V, Figueroa Sandoval JF, Romero F, Labardini Mendez JR, Córdova MS. Ácido fólico, vitamina $B^{12}$ y eritropoyesis. Sangre, 20: 184196, 1975.

8. Waters AH, Mollin DL. Studies on the folic acid activity of human serum. Journal of Clinical Pathology 14: 335-344, 1961

9. Waxmon S, Herbert V. Mechanism of pyrimethamine induced megaloblastosis in human bone-marrow. New England Journal of Medicine 280: 1316-1319, 1969. 